\title{
Comfortably Numb: A Short History of New Zealand Muslim Discourse and Thought
}

\author{
ABDULLAH DRURY
}

\begin{abstract}
This article sketches a history of some of the principle ideas, themes, and values buttressing New Zealand Muslim thought and Weltanschauung. The argument is predicated upon the hypothesis that, in defining religious and spiritual identity, one of the most vital aspects to be taken into consideration are the multiple differences in epistemological, methodological, and ontological assumptions as we try to comprehend the primary sources of religious knowledge and practice. The first section of the article presents the general
\end{abstract}

Abdullah Drury is a University of Waikato MPhil graduate and is researching the history of the New Zealand Muslim community. He holds a BA in History and a Master of Arts with First Class Honours in History from the University of Waikato.

Drury, Abdullah. 2021. "Comfortably Numb: A Short History of New Zealand Muslim Discourse and Thought." American Journal of Islam and Society 38, nos. 1-2: 262-285 • doi: 10.35632/ajis. v38il-2.2872

Copyright (C) 2021 International Institute of Islamic Thought 
heuristic and methodology of describing and demarcating the identities of Muslims, or ways of being a Muslim, in New Zealand, in an existential sense. The second part discusses research that has detected and delineated Muslim identity among New Zealand citizens. The third section elucidates some of the main topics underpinning the worldview of local Muslims, including the precepts of religio-communal authority, autonomy, and agency, and ideas related to the conceptualization and interpretation of Islamic traditions.

\section{Introduction}

Discourse over whether there can be a 'New Zealand Islam' has not ceased since the 1980s, when the idea was articulated by Dr. William Shepard. ${ }^{1}$ Some have vociferously decried the concept as an alien or assimilationist imposition on Muslims for whom Islam does not bear adjectives. ${ }^{2}$ The idea lingers. Since the 2019 Christchurch massacre the case has drawn attention and raised questions: is there not already an indigenous Muslim social unit or identity? Are there not already autochthonous New Zealand Muslim communities with some experience of functioning within a secular state? Indeed, the oldest of these Islamic congregations - the Ponsonby mosque operated by the New Zealand Muslim Association, set up in 1950-has been held up as a potential model for other immigrant Muslim groups and their relationship within a relatively modern secular polity. ${ }^{3}$

It can be argued that the history and practice of New Zealand Islam yields a number of noteworthy lessons for those seeking to cultivate, inculcate, and foster a benign and positive Islam within the country: there is a widespread acceptance of the primacy of the modern secular state apparatus, a loose administrative centralization of the various Muslim institutions, and a pragmatic adaptability towards notions of 'modernity'. ${ }^{4}$ Does this make it a model to be imitated?

This paper interrogates the notion of a 'New Zealand Islam' as being too simple by elucidating the specific historical, political, and 
also intellectual context in which it emerges. In particular, I am concerned to analyze the current popular logic of looking for a particular local Muslim communal identity. One main challenge of my research has been to properly enumerate the points that matter and then assign them weights (that presumably vary with time and place). I will suggest a reflection on what the 'New Zealand model' might mean in three steps: defining the model; placing it in a historical context; and reconstructing the context of the efforts of the contemporary Islamic community to define the local Islamic tradition and negotiate space within a secular society_-and assessing the results.

\section{A New Zealand Model for the World?}

The earliest Muslims to visit New Zealand were lascars, Asian sailors, who were employed aboard European ships. The British colony of New Zealand was created over 1840-1841 when Irishborn Captain William Hobson claimed sovereignty and negotiated a treaty with the native Polynesian tribes. ${ }^{5}$ Established under Queen Victoria, the territory became an independent colony and European-particularly British—immigration increased. In 1852 a legislative chamber was voted in and from 1856 the colony was effectively self-governing in all domestic affairs. In 1907 King Edward VII proclaimed New Zealand a Dominion within the British Empire and four decades later, the polity adopted the Statute of Westminister-confirming loyalty to the British crown but complete autonomy of the New Zealand parliament. ${ }^{6}$

Due to this unique if anodyne colonial heritage, New Zealand is predominately Anglo-European in culture, genomes, faith, and law, but grants special status to the indigenous Polynesian population (called the Maori). In addition to the principal European and Polynesian elements, the gene-pool contains some traces of the lands of various settlers: Africans, Chinese, Indians, and others. This is reflected in the great heterogeneity in skin tone, height, facial and bodily structures, eye and hair color, and so forth. New Zealand is equally heterogeneous in terms of religion, with Atheists, Roman Catholics, Jews, Muslims, 
and Protestants living together in neighborly ties which experience alternating periods of sonorous goodwill and animosity.

The first Muslim family to reside permanently in New Zealand arrived in 1854, when Wuzerah and his family left India and settled near the English colony of Christchurch in the Canterbury province. Initially he worked for Sir John Cracroft Wilson and was later involved in transporting stone from the Port Hills to the famous (Anglican) Christchurch Cathedral when it was constructed in the 1880s. Wuzerah died in 1902. From the 1890s onward men from India came to work across the country and after the 1930s some of these began to bring out wives and children. In 1950 the first Islamic organization was created when the "New Zealand Muslim Association" (NZMA) was established in Auckland, the largest city in the country. The 1951 census recorded just over 200 Muslims in the entire land. ${ }^{7}$ The same year, the MS Goya carried dozens of Muslim refugees from Eastern Europe into New Zealand. In 1959 the NZMA acquired an old house which was restructured for use as the first Islamic Centre. The following year Maulana Ahmed Said Musa Patel (1937-2009) arrived from India to serve as the first official Mullah; for 30 years he led prayers, taught regular Quran classes, and facilitated Islamic education in central Auckland. The first purpose-built mosque in New Zealand was erected by the NZMA in Auckland, over 1979-1980. Throughout the 1960s and 1970s there was a modest trickle of migrants, refugees, and students who aided in the creation of new regional Muslim organizations outside Auckland. For example, the "International Muslim Association of New Zealand" was created in Wellington, the capital, over 1962-64; the "Muslim Association of Canterbury" was formed in Christchurch in 1977. In 1979 there were around 2000 Muslims in all New Zealand and representatives of the regional Associations met to create a new body animated, in part, by a desire to co-ordinate communal affairs at a national level; in April 1979 the "Federation of Islamic Associations of New Zealand" (FIANZ) was formed with MS Goya refugee Mazhar Krasniqi (1931-2019) as the first president. ${ }^{8}$ This was an ardent expression of autonomy and agency, dedication and focus. In 1984 
the Federation secured its first annual halal meat contract with the New Zealand Meat Producers Board, a quasi-governmental office; henceforth all New Zealand meat exported abroad was inspected and certified by local Muslims to ensure it was in fact halal. In 1982 Sheikh Khalid Kamal Abdul Hafiz (1938-1999) from India arrived to serve as imam in Wellington. Over 1984-85 the Muslim Association of Canterbury in Christchurch built the first mosque in the South Island with help from Saudi Arabia. In March 2019, an Australian terrorist murdered 51 worshippers at this mosque and another in the suburb of Linwood, drawing substantial international attention to this small Muslim community. According to the 2018 census there are presently over 57,000 Muslims in all New Zealand. ${ }^{9}$

The initial appeal of the New Zealand model is predicated on two main features: first, it appears to represent a relatively modernized kind of Islamic practice while also being both autochthonous and legitimate; and second, it might have the potential to serve as an example for other Muslim populations across the South Pacific and elsewhere. There seems to be a genuine capacity for adopting modernity inside a Western nation without abandoning religious belief or tradition. ${ }^{10}$ This would suggest that a reasonably centralized and quasi-institutional kind of Islam can be successful within an aggressively secular framework. Whilst we must acknowledge that it is impossible to duplicate these precise institutions elsewhere, nonetheless one can tentatively infer that New Zealand may well serve as a positive societal template.

The French historian Xavier Bougarel has argued that "all of these debates can be boiled down to a central issue: that of the relationship between Islam and Western modernity." "11 Are there clear tendencies towards a sort of New Zealand Islamic modernity? The New Zealand Islamic tradition might be summarized in six bullet points: 1) a highly tolerant Sunni Islam rooted in the Hanafi madhhab (school of Islamic law); 2) the predominance of a broadly South Asian cultural heritage and legacy; 3 ) the Islamization of popular practices; 4) an ameliorating intellectual tradition of reformism within the interpretation of Islam; 5) the institutionalization of Islam 
in the form of the regional Muslim Associations and the national body, the Federation of Islamic Associations; and 6) the practice of Islam as a 'common culture' for Muslims within a specifically AngloEuropean secular state, with an emphasis on compassion and mercy.

It could be argued that Islam in New Zealand might have historically pursued divergent paths, and that the idea of an individualized-personal_-Islam within a secular polity represents only one possible trajectory among others. (It seems to me that identifying Islam as a kind of politicized nationalist ideology would never fly here.) The Bosnian scholar Alija Izetbegovic writes: "Islam is, and should be, a permanent searching through history for a state of inward and outward balance." ${ }^{2}$ This is to argue that the faith should be free of reification, truly supra-cultural and universal in intent, and capable of bridging ethnic and linguistic divisions. In New Zealand the faith is extremely complicated and multi-faceted; it presents an Aladdin's Cave of unique challenges and opportunities to the wider general public, the mainstream non-Muslim society, due to its peculiar economic, legal, political and social features. In addition to purely spiritual concerns, the quodlibetical question of how a secular country can best accommodate this minority faith necessitates in depth consideration. The conundrum of how Muslims as individuals and private citizens can reside within New Zealand is also complicated, but less so. ${ }^{13}$

Increasingly, New Zealand Muslim leaders themselves have presented their Islamic practice as an explicit model for other South Pacific societies. Many presidents of the Federation of Islamic Associations have presented a vision for reciprocal interfaith tolerance and mutual respect, and the development of New Zealand Islamic institutions. ${ }^{14}$ Such declarations have been noticed in government circles: the vision of FIANZ was portrayed in government media as a functional model for Muslims everywhere. ${ }^{15}$ Moreover, for example, Professor Douglas Pratt of the University of Auckland systematically speaks of New Zealand Muslims as autochthonous citizens. In his 2005 book The Challenge of Islam: Encounters in Interfaith Dialogue, he gave elaborate exposition as to what makes New Zealand Islam and Muslims unique and 
indigenous simultaneously, stressing the willingness of immigrant Muslim community leaders to talk publicly of their faith with leaders of other religions. ${ }^{16}$ Firstly, their Sunni tradition of law, since their Hanafi school is considered the most pragmatic. Secondly, the fact that New Zealand Muslims have embraced the English language and did not erect linguistic ghettos. Thirdly, the process of immigration and settlement in a new land effectively meant the end of any pristine religious or ethnic self-isolation, and necessitated interaction and negotiation with another civilization. To some extent, this meant a kind of confrontation with — and an ironic reflection upon - the various styles of philosophy, governance, and both personal and societal behavior. Ultimately, it resulted in a disarticulated and embellished process of securing spiritual autonomy within this new society through the construction and maintenance of self-governing confessional agencies and institutions. Finally, since New Zealand Muslims ceased to be subjects of a dominant religious paradigm and became — willingly_ an ancillary minority living on the periphery of the former British Empire, their faith identity has come to represent a useful universal anchorage for many mu'minūn here. Many New Zealand Muslim leaders have been at pains to emphasize that Islam supports science and human reason, and that there is no contradiction; many have praised the practical advantages of a secular polity whilst idealizing the abstract notion of the theocracy of the Prophet Muhammed alone.

Some might argue for two smaller points: the tradition of Muslim reformist thought and the nature of the Islamic institutions inherited from the South Asian experiences. Traditional ulema and intellectuals inclined towards modernist literature helped to absorb the civilizational shock of the decline (and disappearance) of the Caliphate as an international, universalist centerpoint of the faith. Historically, Abrahamic civilizations were the assiduous product of liberal ambitions restrained by conservative discipline. Throughout the era of the British Raj, most members of the Muslim religious minority of India collaborated and negotiated their place in the evolving hierarchy with undisguised amiability and delight; many 
served diligently in the civil service and the armed forces in order to rectify certain iniquities. The long term societal consequences of modernization — such as the role of women — was not easy. South Asian Muslim leaders frequently had to present a strong case for modernisation predicated on Islamic precepts and terminology. (Curiously, it can be argued that the Islamic reformist tradition became the basis of the Islamic revival movement after the 1970s.)

Although seriously flawed and occasionally quite incompetent, the Federation of Islamic Associations of New Zealand (FIANZ) has become a substantial component of the religious identity of New Zealand Muslims. ${ }^{17}$ The agency certainly proffers itself as a model: created by local immigrants in an era when there were only 2000 Muslims in the entire country, it is self-administered, self-financed, and quasi-democratic. All senior posts are filled through elections - direct at the level of the local congregation (the affiliated regional Muslim Associations) and the presidency of the Federation, and indirect at higher levels, including the various committees. The Muslim Associations and the Federation are ruled by constitutions adhering to New Zealand laws and Islamic sentiments. All ulema are recruited from abroad at the local congregational level, mostly from Asia. As a result of the representative and centralized nature of the Muslim Associations and the Federation, the institution is reasonably adaptable, stable, and most significantly has been able to withstand the danger of overseas radicalization. Indeed, due to its complicated and flexible structure, the Federation was mostly able to impose some moral authority on all affiliated mosques (and most of the outside groups that lean towards fundamentalism), and-although sometimes condemned as a religious chimera-it continues to enjoy some credibility and legitimacy among the faithful it purports to serve and represent.

\section{New Zealand Islamic Institutions in Historical Context}

When I write that the main heritage of the New Zealand Muslims may be their religious foundation and institutionalization within the 
Muslim Associations and the national Federation, I may be endorsing the somewhat overly optimistic appraisals of those who think that New Zealand Islam may be a direct model for the wider South Pacific. Yet these svelte institutions and traditions are organically grown societal phenomena. When examining the 'New Zealand model' in its historical context, it becomes more evident that institutionalization, modernization, self-governance and so forth, may be the results of mostly complex, non-linear, and agonistic historical processes that might have produced different outcomes. Or is this a reflection of the soft bigotry of low expectations?

Beneath our complicated cognitive and social architecture, is a layer of symbolic and dramatic narrative representation that instantiates and punctuates the same ideas and ideals but within a multi-dimensional and multi-faceted context. Religion provides a rich mode of power that an appeal to human reason cannot seriously match, and brings art, architecture, music, literature, and basic societal goods to all humanity. Over time, religion and faith act as a mental bulwark or a buttress - a cognitive structure against the various forces that would destroy society from within, or produce chaos and oblivion as end-goals.

One example of the above-mentioned phenomena can be observed in the public statements and proposals of Mazhar Krasniqi, the inaugural president of the Federation of Islamic Associations. ${ }^{18}$ When the first purpose-built mosque was erected in Ponsonby, central Auckland, he engaged in multi-faceted public diplomacy and spoke on behalf of New Zealand Muslims at a point when many Muslims in the South Pacific had few recognizable representatives, in the aftermath of some rather dramatic situations. For instance, in a 1979 media interview, Krasniqi discussed the growing number of conversions to Islam:

Most of them are people who have come into contact with Islam while travelling in the Middle East. We seem to be getting new members almost every week. If it goes on like this, we will soon be outnumbered by Kiwi Muslims. 
Seriously, though, this is one good reason why we urgently need a mosque - so we can have proper facilities for these new converts. ${ }^{19}$

Alongside this and other declarations of Churchillian proportions, he consistently argued a strong case for the mutual recognition and tolerance of Islam and Christianity_and for human rights, capitalism, and democratic secularism-for the institutionalization of Muslim communities within the framework of New Zealand law. ${ }^{20}$ In summary, Krasniqi modestly argued that life was not composed simply of mendacious tasks and that the Islamic religion was able to speak to the universal ideas and ideals of humanity. He was inferring that the practice of faith gave worshippers that which the ancient Greeks called catharsis (a purification of emotions) as a psychological outcome of prayer; the result could give Believers the ability to better control and regulate their feelings (with the axiom: "what would Muhammad do?"). Over twenty years later, he greeted Kosovar refugees at the Auckland airport:

Ju keni pasur fat ... Zelanda e Re ju garanton të gjitha të drejtat. Këtu sundon ligji ... këtu s'ka të diskriminuar. Ju keni përgjegjësi të dyfishtë, si shqiptarë dhe qytetarë të Zelandës. Këtu do të jeni të respektuar e të mirëpritur ... së bashku do t’i përballojmë të gjitha vështërsitë. ${ }^{21}$

(You are lucky ... New Zealand guarantees you all the rights. There is law here ... there is no discrimination here. You have double responsibility, as Albanians and citizens of Zealand. Here you will be respected and welcomed ... together we will overcome all the difficulties.)

Perhaps such optimism was unrealistic. Whilst new immigrant groups work awkwardly towards degrees of societal integration, there is no precise end in sight for this process. As with communal identities and theological consensus, all institutions-Muslim 
and non-Muslim-develop over time with indefinite and imprecise outcomes. It was not otherwise in New Zealand. Institutional autonomy and the embrace (or toleration) of secularism were as much products of circumstance as results of deliberate action.

Historically, New Zealand Muslims accepted their existence as a minority within a Christian Empire with mixed emotions. Even after acquiescing to the British imperial legacy and modernization as a component of their communal identity (and temporal history), New Zealand Muslims today continue to discuss the era and topic in mostly negative language. For many Muslims the experience was a form of civilizational shock: the yielding of administrative control (supreme executive authority) of Muslim lands to European imperial governance was mitigated by ongoing promises of confessional autonomy and agency. This reminds the reader that it is deceptive and simplistic to decry the late nineteenth and early twentieth centuries as an exceptional era of unremitting colonial tyranny and ghastly imperial subjugation. Various kingdoms and empires had existed throughout chronicled history, and their founding and governing dynasties had always perceived that their hegemony, their social values, and their faith were of benefit to themselves and their subjects.

Curiously, when Muslims in New Zealand later mobilized for religious autonomy after 1950, they often wanted to return to some kind of independent Islamic spirituality but remain under the broad jurisdiction of the Anglo-European legal framework. Their pursuit of religious autonomy was primarily defensive-spurred on by the growing agnosticism or vacuous atheism of the wider society, anxieties and disenchantment related to modernization, and sometimes by a fear of Christian proselytizing. This mobilization was eventually vindicated after the official creation of the various regional Muslim Associations between 1950 and 1980, and the incorporation of the national Islamic Federation in 1979.

Similarly complicated was the destiny of modernist theology within the nascent New Zealand Muslim identity. The sermons and newsletters in favor of a shared life within a secular society 
populated by Christians were responses to existential questions around the ability of Muslim community leaders to interpret Islamic law in order to pragmatically construe precedents in Islamic history and so to help Muslim congregations save face and faith. Even more revealing is the topic of modernist thought. In the effervescent postwar and postcolonial era, young Muslim intellectuals were sharing modernist ideas from Cairo and Istanbul, campaigning for social reforms (such as female empowerment, or at least an improvement in the status of women within Muslim societies) and mainstreaming these ideas. Few intellectual battles were fought between Muslim modernists and traditionalists in New Zealand; for entirely pragmatic reasons, the reformist agenda was largely assumed as the starting point. While many outspoken conservatives and traditionalists could count themselves among prominent community leaders, they were by no means winning the broader culture conflict (especially amongst Muslim youth raised and educated within New Zealand). In fact, New Zealand Muslim youth proved difficult for the conservative voices to rein in. Whilst benefiting from the higher education available, perhaps paradoxically, New Zealand Muslim institutions assimilated aspects of both modernizing tendencies and traditionalist positions. On the subject of the role of females in the public domain, the modernizing trends won the battle although they are still subject to criticisms. ${ }^{22}$ In New Zealand, fear of losing one's Islamic identity through changes in social norms was quite dominant, as was the ideal of social development and progress.

The identification of New Zealand Muslims with aspects of Islamic reformism stems from a later era, namely, the first decade following the creation of the Islamic Federation in 1979. Before this, the Muslim population was very small and many individuals leaned towards simple or traditionalist views of their faith. After 1979, the newsletter of the Islamic Federation expressed educated views of local Muslims that were sometimes at odds with more traditionalist discourses offered by the immigrant ulema. Since then, the Islamic Federation has focused its limited resources on salvaging Islam as a culture and practice. It has succeeded in encouraging and fostering 
Quranic educational objectives and systems. For the most part, its leaders made rational inquiry, reformist thought, and practical legal questions key components of the community newsletters. ${ }^{23} \mathrm{~A}$ mixture of modernist and traditionalist teaching styles dominate mosque efforts to educate youth; all have idealized the concept of an abstract 'Islamic society' but stressed recognition of the secular framework of Islamic practice in New Zealand. Finally, the Federation as institution has cemented its role as the senior national organization of New Zealand Muslims through newsmedia outlets and through the assertion of a monopoly on the certification of Halal foodstuffs in order to finance Islamic activities and events to preserve Muslim identity (and independence from overseas funding sources).

Therefore, there was no straightforward process towards what makes New Zealand Islam unique in New Zealand today. Many of those remarkable characteristics of New Zealand Islam hailed today as liberal or progressive were not really predicated on a modernist consensus or drawn from a book of mirrors for princes, but rather crystallized in complicated processes over some time and frequently arose from sheer Machiavellian necessity. Centralization, reformism, and Islamic education instead became defining elements of New Zealand Muslim self-comprehension relatively recently-at a critical juncture when Islam became a question of identity.

\section{Defending the Tradition}

A second characteristic of the New Zealand model is the fact that local Muslims themselves have begun reflecting the specificity of the 'New Zealand Islamic tradition' and within the broader framework of an evolving multi-ethnic and multi-confessional social pluralism. This has driven state institutions to make active efforts to define and preserve such traditions.

It is noteworthy that what seems to be the foundation of the official self-comprehension of New Zealand Muslims (as defined above) is that there is a blur in distinctions between ethnicity and religion - the exact demarcations are loose and often defined in 
relation to the Anglo-European majority population. The definitions of 'multi-culturalism' remain anfractuous and noncommittal (deliberately so, one suspects). For instance, personal spiritual beliefs and practices are seldom treated as a 'custom' or 'tradition' but as a 'religion' entirely in the Western sense. The Sunni tradition of Islam became the quasi-official position of the Islamic Federation but the exact madhhab has never been defined by Muslim community representatives. The underlying rationale of such discursive orientations is that the broadest sense of the Sunni tradition is not only a pragmatic self-definition, but also a useful instrument of self-positioning in a religious context that has suddenly become confusingly pluralistic.

Since the global Islamic resurgence after 1980, New Zealand Muslims have faced three kinds of challenges: the politicization of faith in various malevolent international shenanigans; increased activity by outside agents eager to influence the domestic Muslim community; and finally, the pluralization of the Muslim community within New Zealand itself. All have thrown into question the autonomy and agency of the Islamic Federation in New Zealand. The Federation has struggled but gradually learned to answer and negotiate those challenges. With substantial Halal certification fees, it has built a modest infrastructure, fostered the study of classical (Quranic) Arabic, founded multiple committees and activities, and managed to negotiate a space within New Zealand society. ${ }^{24}$ However the most demanding challenge proved to be the growing internal pluralism inside New Zealand itself.

Since the 1990s, the penetration of various Islamic trends into New Zealand contributed to an evolving recalibration in Muslim communal discourse over Islam in New Zealand. Changes to immigration laws and influxes of African and Asian refugees created new Muslim communities. Presently the array of Muslim congregations and organizations will remind sage readers of the taifa kingdoms of Moorish Spain. Many hitherto absent, eccentric, or quiescent ideas and kinds of Islamic spirituality grew and spread rapidly, including minority sects such as the Ahmadiya and the Shia, Sufi groups and 
manifestations of neo-Salafism. ${ }^{25}$ Auckland, the largest city in the country, until recently home to a single Muslim association and one mosque, is now home to over thirty such organizations and a multiplicity of Islamic congregations of varying sizes.

All of these trends represented real challenges but at differing levels. Several groups openly questioned the monopoly of the Islamic Federation-either to represent all Muslims or to certify Halal foodstuffs. Some began offering alternative fatwas and voices on differing media and through various channels. Certain community leaders also openly disputed the legitimacy of some traditional religious practices (such as the Milad-an-Nabi), funeral rituals, the calculation of Ramadan timings, and so forth.

Dissident Islamic discourse was disseminated by germane translations of pious literature and small Islamic centers created in suburbs. ${ }^{26}$ Lay preachers initiated fierce attacks on the legitimacy of the Islamic Federation, and because some were educated in Arabia they could assert their differing vision of Islam on their mastery of Arabic (giving them an aura of conservative authenticity). These developments escalated in attempts by dissenting groups to occupy or take over mosques. ${ }^{27}$ Finally, in 2012-2013, a few individuals left for Syria and threatened reality from the fantasy of the Caliphate there. ${ }^{28}$

In a slow-witted response, the Islamic Federation sought to reaffirm its kenspeckle authority and legitimacy. Over the years, it followed two very broad strategies: soft and strict. Firstly, the Islamic Federation has called upon the ulema and the umma to be unswerving in their commitment to Islam on the basis of the Qur'an and the Sunnah; secondly, the Federation reaffirmed their sole authority over religious subjects like Halal certification..$^{29}$ As became obvious, proclaiming authority is not the same thing as possessing it. It became necessary to look for other channels to legitimize the irenic claims of the Federation and to defend that which the challengers implicitly attacked (the idea of a New Zealand practice of Islam).

Although the Islamic tradition of New Zealand Muslims has been much trumpeted, in reality it remains an ephemeral and often vague reference. Attempts to provide the New Zealand Muslim tradition an 
explicit rationale or a precise definition should have become one of the principle strategies for countering extremism or radical interpretations of Islam. ${ }^{30}$ This is an important point. The American scholar John Lukacs wrote: "History and life consist of the coexistence of continuity and change. Nothing vanishes entirely." ${ }^{11}$ Once a social unit permits a distorted or corrupted account of their past - religious or secular - to seize the high moral ground in the group discussion, then dissonance quickly emerges and transforms into expressions of anarchy, chaos, and disorder. What we think about history shapes how we think about ourselves in the present and influences the decisions we make in the future. (Saint Augustine insisted that the seat of the human mind was in memory.) A loss of faith in the structures of democratic governance or personal rights is dangerous for all citizens.

A precise definition of New Zealand Islam should have proved a useful basis on which the Federation could fully reassert its authority. It would allow for the legitimization of an otherwise relatively empty notion by developing and institutionalizing the local tradition. The Federation should have undertaken the task of researching the history of New Zealand Muslims, including its vagaries and vicissitudes, engaging in public discussions about these experiences and traditions. It should have started publishing literature on New Zealand Muslim characters, leaders, and thinkers in order to build a corpus of domestic Islamic knowledge production-providing a firmer empirical foundation for the claims to a distinctive local Islamic tradition. The Federation ought to have begun regular public conferences on the ideas around Islamic customs, culture, and tradition. ${ }^{32}$ Such symposiums would have allowed for pluralistic debate over what constitutes the New Zealand Islamic tradition exactly, to raise and answer arguments for its Islamic roots and legitimacy.

\section{Liberal Process of Constructing a Tradition Rather Than Tradition of a Liberal Islam}

While the precise meaning of the Islamic tradition of the New Zealand Muslims remains somewhat suspended between official 
and critical discourses that do not always converge, the Federation of Islamic Associations of New Zealand has succeeded in tentatively establishing a loose abstract concept of a type of New Zealand Islamic practice capable of uniting a community of immigrants, refugees, and converts, that was also worth preserving and open to some measure of dialogue.

I think it is important to remember that-theoretically and theologically — one cannot really add an adjective to 'Islam' as such. It is always slightly inaccurate to write of 'New Zealand Islam' versus 'Australian Islam' for example, or 'Arab Islam'. Rather than trying to seek geographic or theological demarcations thus, I suspect it is more helpful to list — and perhaps prioritize - the characteristics and features of Islam that local Muslims care most about. ${ }^{33}$ Custom and culture are different from tradition: the latter is predicated on adherence to definite values, but it is also a product of a shared communal history and other social norms (such as coexistence, integration, and secularity). Discussing 'culture' and 'tradition' allows one to examine a universal system of ethical and religious norms in an explicit manner. Only through culture and tradition can reform and secularism really become a component of that to which a social group may be asked to adhere to. As Lukacs expressed, "After all, everything a man does depends on some kind of belief. He will speak or act in a certain way because he thinks that this kind of speaking or acting is better than another." ${ }^{34}$ Finally, tradition permits social units to define their own identity without fostering serious societal divisions - the New Zealand Muslim tradition is largely a part of the tolerant Sunni tradition, and therefore part of the wider global Islamic tradition.

For example, even if only the Islamic Federation is recognized to certify Halal foodstuffs, many individuals and groups-including acerbic and hostile voices - have participated in wider public debates on the topic. ${ }^{35}$ The various conferences, meetings, and reports on the subject have all demonstrated signs of mutual recognition between certain critical trends and the official institutions: a distinction is made between those Muslim individuals 
and groups who criticize specific features of the Halal certification process (that is, those who despite reservations do recognize the Islamic Federation), and those actors and agencies that dispute the Federation outright. ${ }^{36}$

So, the process of constructing and fostering a New Zealand Halal tradition has proven flexible enough to gradually incorporate diverse opinions and views, without automatically creating serious divisions or disrupting the national economy. It has also permitted an evolution of policy and perceptions, and even for a convergence on certain other subjects on a relatively conservative basis. The success and triumph of tradition as a process does confirm the point that extremes and strife can be prevented. The internal challengers have for the most part accepted the utility of a shared communal framework for defining shared ethics here, but also recognized the agency of the Federation in that very process. Presently, conservative or neo-Salafi voices are less concerned with Halal certification and more on pragmatic issues of social relations (family matters and religious morality, the hijab and pornography). ${ }^{37}$

Thus, the open process of tradition-determining does not make the New Zealand practice of Islam 'liberal' from a Western perspective. Rather, there is a constant need to establish or prove Islamic legitimacy in the sense of a defense of the faith. A 'tradition' might be tugged towards communal or socially conservative positions, or towards a tolerance of such positions at the very least. The oscillation between a rational vision of an individualist religion of Islam versus a more communal, conservative project will probably always be present.

However, it can be argued that the process itself makes the tradition 'liberal' in another sense. The Muslim institutions of New Zealand proved more than capable of negotiating a complex path, through a glutinous plurality of policies and positions, ideologies and influences. This robust and resilient capacity for development through a practical code of rules whilst preserving a link to its foundational spiritual norms might even be interpreted as a mark of secularity. ${ }^{38}$ New Zealand Muslim organizations frequently invoke 
both conservative Islamic religious authority and their status within the New Zealand legal framework, whilst simultaneously pursuing legitimacy through the inclusion and persuasion of most of their opponents.

\section{Conclusion}

The growth and expansion of the Muslim community and Islam in New Zealand has generally echoed international trends but with multiple local features and idiosyncrasies. Modern New Zealanders are not really a nation drawn from a single source but instead form a spectrum of confederal social units with similar but differing cultures and language skills. In recent years, it has become popular in New Zealand to decry the British heritage and promote Maori nationalism. In reality, this country, as a modern nation-state, is built on the basis of a solid British colonial legacy - in culture and laws. Within most New Zealand Muslim self-descriptions, the New Zealand form and practice of Islam is usually predicated on a centralized institution (the Islamic Federation) and the wider experience of communal secularism and pluralism. Such a proficient self-perception does not mirror an obvious model — that is to say, a clear and precise list of ingredients and values for a 'liberal' or 'progressive' type of Islam. Rather it is the mark of fruitful exertions and efforts to locate appropriate replies to the multiple existential challenges posed by the realities of religious pluralism and globalization, and challenges to spiritual activity, agency, authority, and autonomy through the creation and fostering of a 'New Zealand tradition of Islam'.

Some four decades ago, the New Zealand Muslim community began a process to reaffirm its religious roots, authority, and legitimacy. This process is still being negotiated. Presently, it appears to possess and lean towards a more practical orientation in terms of framing basic religious and ideological tensions. For example, all the mosques in this country were built largely through voluntary subscription (private donations); partly because of the massive 
geographical distances involved, overseas contributions have been rare and noteworthy. Overall, this approach has helped to direct and channel disagreements into discursive processes to resolve controversies; disputes have contributed towards open-ended yet controlled community identity formation. Whilst the emergent identity is complex and ongoing, it bears a procedural character that unfolds within a modern, secular-leaning framework that favors personal human rights, capitalism, and democratic forms.

Not every Muslim congregation in New Zealand bears its own specific immigrant 'tradition'; however, most diasporic Muslim minorities in this country are very pluralistic (if not divided in their respective group traditions and hierarchical proclivities). In the Islamic Federation, most New Zealand Muslims have the advantage of being associated with, or represented by, an organization that is complicated and adaptable enough to develop, engage, and negotiate in self-reflective processes to a greater or lesser extent. Rather than an overly precise set of reified principles, the model of the Islamic Federation of New Zealand revolves around a practical and prudent organization of religious life. ${ }^{39}$ 


\section{Endnotes}

1 William Shepard, "Muslims in New Zealand," Journal of Muslim Minority Affairs 4, nos. 1 \& 2 (1982): 60-81.

2 The term 'New Zealand Muslim' lacks the rigid definition of a Linnaean taxonomic grouping and resembles more a toyshop grab-bag of traits that one could stick together into an appropriately religious identity.

3 For a historical overview of Islam and the Muslim population of New Zealand, see Abdullah Drury, "Mahometans on the Edge of Colonial Empire: Antipodean Experiences," Islam and Christian-Muslim Relations 29, no. 1 (2018): 71-87; Abdullah Drury, "Once Were Mahometans: Muslims in the South Island of New Zealand, mid-19th to the late 20th century, with special reference to Canterbury,” MA thesis, University of Waikato, Hamilton, 2016; William Shepard, "New Zealand Muslims and Their Organisations," New Zealand Journal of Asian Studies 8, no. 2 (2006): 4-44.

4 Erich Kolig, "An Accord of Cautious Distance: Muslims in New Zealand, Ethnic Relations and Image Management," New Zealand Journal of Asian Studies 5, no. 1 (2003): 24-50.

5 For an excellent introduction to the establishment of modern New Zealand, see Paul Moon, This Horrid Practice (Auckland: Penguin, 2008); Stuart C. Scott, The Travesty of Waitangi: Towards Anarchy (Dunedin: Campbell Press, 1995); David Round, Truth or Treaty? Commonsense Questions About the Treaty of Waitangi (Christchurch: University of Canterbury Press, 1998); Kenneth R. Minogue, Waitangi: Morality and Reality (Wellington: New Zealand Business Roundtable, 1998).

6 James Belich, Making Peoples: A History of the New Zealanders from Polynesian Settlement to the End of the Nineteenth Century (North Shore: Penguin, 2007).

7 New Zealand Population Census 1951, Volume III-Religious Profession (Wellington, 1953), 9.

8 Ainsley Thomson, "Mazhar Krasniqi," New Zealand Herald, 31 December 2002, A6; Zohoor Mohammad Khan, "Mazhar Shukri Krasniqi,” One Hundred Great Muslim Leaders of the 20th Century (New Delhi: Institute of Objective Studies, 2006), 157-160; Sabit R. Abdyli, Bijtë e shqipes në tokën 
e reve të bardha (Auckland: Universal Print \& Management, 2010), 88-90; Kurt Bayer, "Kaumatua' of Muslims in NZ dies aged 87," New Zealand Herald, 22 August 2019, A19.

9 See Drury, "Mahometans on the Edge of Colonial Empire"; Shepard, "New Zealand Muslims and Their Organisations"; Erich Kolig, New Zealand's Muslims and Multiculturalism (Leiden: Brill, 2010).

10 Joanna Wane, “Test of Faith,” North E South (June 2016): 36-49.

11 X. Bougarel, "Bosnian Islam as 'European Islam': Limits and Shifts of a Concept," in Islam in Europe: Diversity, Identity and Influence, edited by A. Al-Azmeh and E. Fokas (Cambridge: Cambridge University Press, 2007).

12 Alija Izetbegovic, Islam between East and West (Plainfield, Indiana: American Trust Publications, 1993), xxxii.

13 Islam is singular among the main global religions in its explicit stress on the principles of governance and state operations. In some respects, these predilections are deemed to be as significant as the precepts underlying private behaviour, beliefs, practices, and ethics. Historically Muslims lived within Islamic polities and important sections of Islamic teaching were related to the issue of benign and just political administration: how best to rule a society fairly along divine lines. It has taken until recent decades for serious Islamic scholars and theologians to write detailed opinions relating how Muslims should live as minorities with no real political authority. This aspect contributes to the state of confusion, flux, and internal tension within Muslim congregations.

14 Thomson, "Mazhar Krasniqi"; Ismail Waja, "50 Years Celebrations," Al Mujaddid (July 2001), 1-2, 7.

15 Ian Clarke, "Essentialising Islam: Multiculturalism and Islamic Politics in New Zealand," New Zealand Journal of Asian Studies 8, no. 2 (2006): 69-96.

16 Douglas Pratt, The Challenge of Islam: Encounters in Interfaith Dialogue (Aldershot: Ashgate, 2005); William Shepard, Introducing Islam (London: Routledge, 2009).

17 Wane, "Test of Faith."

18 For more on Mazhar Krasniq, see Thomson, "Mazhar Krasniqi”; Beyer, “Kaumatua' of Muslims in NZ dies aged 87." 
19 Peter Trickett, "Minarets in Ponsonby," The New Zealand Listener, 21 April 1979, 18-19.

20 “Eastern Dome For Skyline,” New Zealand Herald, 7 April 1980, 2; "City Mosque For Muslims,” New Zealand Herald, 28 March 1979, 1.

21 Abdyli, Bijtë e shqipes në tokën e reve të bardha, 69.

22 Kolig, New Zealand's Muslims and Multiculturalism, 140.

23 Shepard, "New Zealand Muslims and Their Organisations."

24 Kolig, New Zealand's Muslims and Multiculturalism, 140-141.

25 Shepard, "New Zealand Muslims and Their Organisations."

26 Erich Kolig, "Interfacing with the West: Muslims, Multiculturalism and Radicalism in New Zealand," New Zealand Sociology 21, no. 2 (2006): $215-246$.

27 Lincoln Tan, "If I was a Terrorist, I'd be in Hiding," New Zealand Herald, 13 May 2014, 5; Lincoln Tan, "Jihad Threat to Mosque Security,” New Zealand Herald, 20 May 2014, 11; "Imam at Centre of Mosque Uproar Kept Under Police Surveillance," New Zealand Herald, 24 May 2014, 3.

28 David Garrett, "Muslim Immigration: The Political Dilemma," Investigate (August-September 2014), 10-11; "Isis Supporter has Nothing to Hide, Decries Atrocities," Waikato Times, 8 November 2014, 3; "Kiwi Jihadi Labelled a Terrorist by United States,” Press, 1 April 2017, 2; Jason Walls, "Peters Lashes Out at Jihadi," New Zealand Herald, 6 March $2019,14$.

29 Clarke, "Essentialising Islam."

30 Shepard, "New Zealand Muslims and Their Organisations."

31 John Lukacs, At the End of an Age (New Haven: Yale University Press, 2002), 31 .

32 Kolig, New Zealand's Muslims and Multiculturalism, 20-49.

33 Izetbegovic, Islam between East and West.

34 John Lukacs, At the End of an Age (New Haven: Yale University Press, 2002), 58.

35 Rizwan Mohammad, "Halal more than just food-theme of Islam Awareness Week 2018,” Indian Weekender, 7 September 2018, 11. 
36 Chun Foo-Yuen "The Dynamics of the Halal Meat Trade in New Zealand and Australia," New Zealand and the Middle East, ed. Ron MacIntyre (Christchurch: Australasian Middle East Studies Association, 1987), 149-176.

37 Kolig, New Zealand's Muslims and Multiculturalism, 20-40.

38 See Charles Taylor, A Secular Age (Cambridge, MA: Harvard University Press, 2007).

39 Drury, "Mahometans on the Edge of Colonial Empire"; Shepard, "New Zealand Muslims and Their Organisations.” 